\title{
PENEGAKAN HUKUM TERHADAP ZONA LARANGAN TERBANG BAGI PESAWAT SIPIL ASING DI INDONESIA
}

\author{
Silmiwati \\ Mahkamah Agung Republik Indonesia \\ Email : silmiamy94@gmail.com
}

\begin{abstract}
The sovereignty is the highest authority owned by the state. In the sovereignty decided contained matter relating with the power and responsibility for the state territory. The state have a responsibility to own territory and that state has the power to be competent for apply the no-fly zone. Indonesian state is the sovereign state, therefore with the implementation of no-fly zone meant that no reduction in the sovereignty of Indonesian state. The results showed that no-fly zone was regulated in International Law on Paris Convention 1919 Article 3 and 4, and Chicago Convention 1944 Article 9. The National Law, no-fly zone was regulated on Article 7 Legislation Number 1 of 2009 about Aviation. Indonesia has setting the rule of no-fly zone in the region WAP7 Surabaya Naval Base and WAP23 Balikpapan Flare. Indonesia Air Force has working to maintain the sovereignty of Indonesia.
\end{abstract}

\section{Keyword : Sovereignty; Flight; Civil}

\begin{abstract}
ABSTRAK
Kedaulatan adalah otoritas tertinggi yang dimiliki oleh negara. Dalam kedaulatan diputuskan berisi hal-hal yang berkaitan dengan kekuasaan dan tanggung jawab untuk wilayah negara. Tujuan yang diharapkan dari penelitian ini yaitu mengetahui penegakan hukum terhadap zona larangan terbang bagi pesawat asing di Indonesia. Hasil penelitian menunjukkan Indonesia telah menetapkan aturan zona larangan terbang di wilayah WAP7 Pangkalan Angkatan Laut Surabaya dan WAP23 Balikpapan Flare. Angkatan Udara Indonesia telah bekerja untuk menjaga kedaulatan Indonesia.
\end{abstract}

\section{Kata Kunci : Kedaulatan; Penerbangan; Sipil}

\section{Pendahuluan}

Kedaulatan negara merupakan salah satu hal yang sangat penting untuk dijaga oleh suatu negara. Negara yang berdaulat diartikan sebagai negara yang mempunyai kekuasaan tertinggi (supreme authority) yang berarti bebas dari kekuasaan negara lain, bebas dalam arti seluas-luasnya baik ke dalam maupun ke luar.
Didalam kedaulatan yang dimiliki oleh negara terkandung hal-hal yang berhubungan dengan kekuasaan dan tanggung jawab negara terhadap wilayahnya. Sebagai negara yang berdaulat suatu negara dapat mengatur wilayah darat, laut dan udara baik untuk kepentingan pertahanan, keamanan, keselamatan penerbangan, maupun kegiatan sosial lainnya.

Untuk mempertahankan wilayah- 
wilayahnya tersebut negara menerapkan berbagai aturan, baik yang merupakan hukum nasional maupun yang berasal dari hukum internasional seperti perjanjian mengenai perbatasan di darat dan di laut dengan negara-negara terdekat. Begitupun dengan udara di atas wilayah teritorialnya, negara menerapkan aturan nasionalnya demi menjaga keutuhan kedaulatan negara.

Wilayah kedaulatan negara yang mencakup ruang udara di atas wilayah darat dan laut suatu negara ditegaskan dalam Pasal 1 Konvensi Chicago 1944 yang berbunyi "The Contracting States recognize that every State has complete and exclusive sovereignty over the airspace above its territory" (Setiap negara mempunyai kedaulatan yang penuh dan eksklusif atas wilayah udara diatas wilayah teritorialnya).

Dalam mempertahankan kedaulatan negara, keutuhan wilayah negara, dan keselamatan segenap bangsa dari ancaman dan gangguan terhadap keutuhan bangsa dan negara maka negara mempuyai kewenangan dalam penyelenggaraan pertahanan negara. ${ }^{1}$ Setiap negara mempunyai standar penjagaan ruang udara wilayahnya secara ketat. Ruang udara nasional suatu negara sepenuhnya tertutup bagi pesawat udara asing baik sipil maupun militer dan hanya dengan izin dari negara kolong terlebih dahulu baik melalui perjanjian bilateral maupun multilateral,

${ }^{1}$ Pasal 1 angka 1 Undang-Undang Nomor 3 tahun 2002 tentang Pertahanan Negara maka ruang udara nasional dapat dimasuki atau dilalui pesawat udara asing. ${ }^{2}$ Negara berhak dalam menentukan wilayah udara mana yang boleh dilewati oleh pesawat sipil dan penetapan tersebut juga harus disesuaikan dengan peraturan yang telah diatur Konvensi Chicago 1944 dan yang ditetapkan Organisasi Penerbangan Sipil Internasional.

Sepanjang menyangkut zona udara terlarang diatur dalam Pasal 9 Konvensi Chicago 1944. setiap negara berhak menetapkan zona larangan terbang bagi pesawat udara sipil asing dan militer asing bahkan larangan tersebut berlaku juga terhadap pesawat sipil nasional. Larangan terbang diterapkan oleh negara-negara dengan berbagai alasan salah satunya ialah dengan semakin berkembangnya teknologi di ruang udara tidak menutup kemungkinan terjadinya pelanggaran-pelanggaran seperti pemotretan dari udara melalui satelit, ataupun adanya kegiatan spionase yang dilakukan oleh musuh yang dapat mengganggu kedaulatan suatu negara. Terkait dengan alasan keamanan militer dan keselamatan publik, penetapan zona larangan terbang tersebut bertujuan menjaga keamanan dan ketertiban suatu negara.

Salah satu bentuk penerapan zona larangan terbang ialah pada kasus yang pernah terjadi di zona larangan terbang Uni

\footnotetext{
2 Pasal 6 Konvensi Chicago 1944 tentang Convention of International Civil Aviation
} 
Soviet pada tahun 1983. Pelanggaran wilayah udara merupakan suatu keadaan, di mana pesawat terbang suatu negara sipil atau militer memasuki wilayah udara terlarang atau tanpa izin memasuki wilayah udara negara lain. Indonesia telah menetapkan zona larangan terbang berdasarkan Aeronautical Information Publication (AIP) Indonesia yaitu di WAP7 Surabaya Naval Base dan WAP23 Balikpapan Flare.

Permasalahan yang akan dibahas dalam tulisan ini yaitu bagaimana penegakan hukum terhadap zona larangan terbang bagi pesawat sipil asing di Indonesia. Tujuan yang diharapkan adalah mengetahui penegakan hukum terhadap zona larangan terbang bagi pesawat asing di Indonesia.

\section{Metode Penelitian}

Dalam penulisan hukum ini menggunakan penelitian hukum normatif (doktrin) yang bersifat deskriptif, yaitu penelitian normatif yang dapat diartikan sebagai suatu prosedur pemecahan masalah yang diteliti dengan mengambarkan atau melukiskan keadaan objek atau subjek yang diteliti pada saat sekarang berdasarkan fakta yang tampak atau sebagaimana adanya. Pendekatan penelitian yang digunakan dalam penulisan ini adalah deskriptif analitis.

\section{Hasil dan Pembahasan}

Penggunaan alat transportasi udara baru populer sejak permulaan abad ke-17, berbeda dengan alat transportasi laut yang telah ada jauh sebelumnya. Pada masa itu manusia terbang dengan pesawat udara yang menggunakan udara yang dipanaskan. Selain menggunakan pesawat udara sederhana, manusia juga mencoba terbang menggunakan balon yang diisi dengan zat cair dan ada juga balon yang menggunakan gas. ${ }^{3}$

Penerbangan internasional bisa dikatakan sebagai penerbangan lintas negara, dimana dalam pelaksanaannya harus mematuhi peraturan baik itu peraturan internasional maupun peraturan nasional negara masing-masing. Pelaksanaan penerbangan internasional dengan adanya perjanjian antar negara, baik itu perjanjian bilateral maupun multilateral.

Masalah status hukum ruang udara di atas wilayah daratan dan perairan suatu negara berdaulat yang digunakan untuk melakukan penerbangan, mulai dibahas secara resmi dalam Konferensi Paris 1910 yang berlangsung dari 10 Mei dan berakhir 29 Juni 1910. Latar belakang Konferensi Paris 1910 adalah kenyataan banyaknya penerbangan yang berlangsung di Eropa, tanpa memperhatikan kedaulatan negara di bawahnya, karena pada saat itu belum ada pengaturannya. ${ }^{4}$

\footnotetext{
${ }^{3}$ K. Martono dan Ahmad Sudiro, Hukum Udara Nasional dan Internasional Publik, Rajawali Pers, Jakarta, 2012, hlm. 9

${ }^{4}$ K. Martono, op.cit, hlm: 11
} 
Namun Konferensi yang Chicago yang menghasilkan Konvensi dilangsungkan di Paris 1910 tidak berhasil Chicago 1944 yang secara langsung mencapai pemecahan yang bulat tentang membahas tentang penerbangan sipil. pelaksanaan penyelesaian masalah mengenai Pembahasan penerbangan sipil yang telah pengaturan ruang udara di atas wilayahnya. dimulai pada Konvensi Paris, di nilai banyak Kegagalan tersebut disebabkan oleh kekurangan namun hal itu perlu diakui keberatan Inggris menerima usul perubahan sebagai salah satu usaha untuk merumuskan undang-undang perdatanya, khusus mengenai status hukum hak-hak milik perorangan dari si pemilik tanah di ruang udara, tidak terdapat kata sepakat di dalam konvensi untuk mengadakan perlakuan yang sama kepada pesawat udara asing dan pesawat udara nasional, dan adanya kepentingan politik. ${ }^{5}$

Dengan di tandatanganinya Perjanjian Perdamaian Penerbangan pada tahun 1919, maka sebagai pelaksanaannya, yakni Konvensi Paris yang telah ditandatangani pada tanggal 13 Oktober 1919 dan mulai berlaku pada tanggal 11 Juli 1922. Konvensi Paris yang berjudul Convention Relating to the Regulation of Aerial Navigation. Penerbangan internasional mulai diatur di dalam Konvensi Paris 1919.

Namun dalam penerapannya Konvensi ini, masih terdapat kekurangan, dimana Konvensi tersebut sangat diskriminatif baik terhadap sesama negara anggota maupun bukan negara anggota Konvensi Paris 1919.

Dengan kekurangan tersebut maka pada tahun 1944 diadakan konferensi di 
dilihat dari sejarah penerbangan yang sudah terjadi sebelumnya, banyaknya pesawatpesawat udara yang terbang diatas wilayah yang merupakan kawasan militer suatu negara. Oleh karena itu Konvensi Paris 1919 telah memberikan hak penuh kepada negara dalam menentukan boleh atau tidaknya pesawat memasuki wilayah udara negara. Penerapan zona larangan terbang ini sejalan dengan Pasal 1 Konvensi Paris 1919.

Zona larangan terbang tidak boleh diskriminasi antara pesawat udara sipil nasional dengan atau pesawat udara sipil asing satu terhadap yang lain. Zona larangan terbang di tetapkan oleh negara karena adanya suatu kegiatan militer di bawah wilayah udara, sehingga untuk menjaga stabilitas keamanan dan pertahanan negara. Namun zona terlarang tidak semata-mata di tetapkan untuk menjaga kepentingan militer suatu negara saja, zona larangan terbang juga memberikan suatu bentuk keamanan dan keselamatan dalam penerbangan agar dalam penerbangannya pesawat tidak terganggu dan tidak mengganggu kegiatan militer yang ada di bawahnya.

Dalam Konvensi Chicago 1944, zona larangan terbang atau prohibited area diatur di dalam Pasal 9 Konvensi Chicago 1944. Konvensi ini memberikan kewenangan kepada negara dalam menetapkan wilayah yang boleh dan tidaknya dilalui pesawat terbang. Agar tidak adanya kesewenangan dari tindakan suatu negara, Konvensi
Chicago memberikan batasan terhadap alasan apa yang boleh dijadikan sebagai wilayah udara suatu negara tersebut terbatas dan/atau terlarang. Zona larangan di bentuk demi menjaga keamanan dan pertahanan suatu negara dan juga demi keselamatan penerbangan. Zona larangan terbang dapat diterapkan kepada daerah konflik ataupun daerah non konflik. Penerapan zona larangan terbang juga harus disesuaikan dengan sewajar mungkin agar tidak mengganggu navigasi penerbangan dan sesegera mungkin di umumkan kepada negara lain dan juga kepada organisasi penerbangan sipil internasional.

Penerapan zona larangan terbang dapat diterapkan di kawasan terlarang dan kawasan berbahaya. Menurut Pasal di atas bahwa zona larangan terbang dapat berubah-ubah, jika ditetapkan dalam keadaan darurat seperti jika suatu negara sedang terjadi konflik perang atau wilayah tersebut merupakan daerah rawan bencana yang dapat menimbulkan kerusakan pada navigasi penerbangan. Pada intinya zona larangan di tetapkan sebagai bentuk perlindungan terhadap pesawat udara terutama pesawat sipil.

Dalam hukum nasional masalah penerbangan diatur di dalam UndangUndang Nomor 1 Tahun 2009 tentang penerbangan, Undang-Undang ini terdiri dari 23 bab dan 466 pasal. Ketentuan tentang zona larangan terbang diatur di dalam diatur 
di dalam Bab IV bagian Kedaulatan Negara Pasal 7.

Kemudian zona larangan terbang juga disebut di dalam Peraturan Pemerintah Nomor 3 Tahun 2001 tentang Keamanan dan Keselamatan. Pengaturan zona terlarang atau di dalam peraturan pemerintah ini disebut sebagai kawasan udara terlarang diatur dalam Pasal 1 angka 10.

Wilayah udara Indonesia dibagi ke dalam 3 bentuk kategori, yaitu kawasan berbahaya (danger), kawasan terlarang (prohibited), dan kawasan terbatas (restricted). Kawasan berbahaya (danger) diartikan sebagai ruang udara tertentu di atas daratan dan/atau perairan, yang sewaktuwaktu dapat terjadi aktivitas yang membahayakan penerbangan pesawat udara. Kawasan terlarang (prohibited) diartikan sebagai sebuah wilayah udara di atas daratan dan/atau perairan teritorial suatu Negara, di mana pesawat udara dilarang terbang melalui ruang udara tersebut karena pertimbangan pertahanan dan keamanan negara serta keselamatan penerbangan. Kawasan terbatas (restricted) diartikan ruang udara tertentu di atas daratan dan/atau perairan, karena pertimbangan pertahanan dan keamanan atau keselamatan penerbangan atau kepentingan umum, berlaku pembatasan penerbangan bagi pesawat udara yang terbang melalui ruang udara tersebut.

Perbedaan dari ketiga kawasan tersebut ialah dapat dilihat dalam penggunaannya, kawasan berbahaya digunakan ketika terdapat potensi bahaya untuk penerbangan, yang sewaktu-waktu dapat berubah-ubah, sebagai contoh kawasan gunung berapi aktif. Sedangkan kawasan terlarang digunakan untuk kepentingan keamanan dan pertahanan negara yang mana benar-benar dilarang untuk penerbangan pesawat sipil serta penetapan ini bersifat permanen dan menyeluruh bagi pesawat sipil nasional dan pesawat sipil asing, larangan tersebut hanya dapat ditetapkan di dalam wilayah udara Indonesia, sebagai contoh instalasi nuklir, istana Presiden dan pangkalan militer. Dan untuk kawasan terbatas, kawasan udara dengan pembatasan bersifat tidak tetap dan hanya dapat digunakan untuk operasi penerbangan tertentu seperti pesawat udara TNI. Pada waktu tidak digunakan atau tidak aktif, kawasan ini dapat digunakan untuk penerbangan sipil. Pembatasan dapat berupa pembatasan ketinggian dan hanya dapat ditetapkan di dalam wilayah udara Indonesia, misalnya instalasi atau area pelatihan militer.

Penetapan kawasan tersebut diatas didasarkan pada AIP (Aeronautical Information Publication $)^{7}$ Indonesia bagian Enr 5 Navigation Warning. Dalam AIP Indonesia, daerah yang dijadikan sebagai kawasan tersebut diberikan kode, untuk

\footnotetext{
${ }^{7}$ Aeronautical Information Publication merupakan publikasi yang dikeluarkan oleh atau dengan otoritas Negara dan berisi informasi aeronautika untuk kepentingan navigasi udara.
} 
kawasan terlarang dengan kode $P$, kawasan terbatas dengan kode $R$, dan kawasan berbahaya dengan kode $D$. Dalam pengawasannya, ketiga kawasan tersebut diawasi oleh Air Controller yang berada di Pusat yaitu di Jakarta dan Air Controller yang berada di Makassar, sehingga untuk membedakan pengawasannya, AIP memberikan kode WI untuk wilayah pengawasan sektor Jakarta dan WA untuk wilayah pengawasan sektor Makassar.

Dalam menjalankan penegakan hukum di wilayah udara Indonesia, diperlukannya keseragaman peraturan yang diberlakukan untuk keselamatan navigasi penerbangan pesawat sipil, sehingga antara hukum nasional dan internasional tidak saling bertentangan, adapun unsur-unsur untuk melakukan pencegatan terhadap pesawat seharusnya memperhatikan sebagai berikut: ${ }^{8}$

a. Praktik intersepsi pesawat sipil tidak akan dilakukan;

b. Intersepsi pesawat sipil dilakukan hanya sebagai jalan terakhir;

c. Jika dilakukan, intersepsi hanya terbatas menentukan identitas pesawat, kecuali diperlukan untuk mengarahkan pesawat kembali ke jalur yang direncanakan, mengarahkannya luar batas-batas wilayah udara nasional, panduan mengarahkan untuk menjauhi

\footnotetext{
${ }^{8}$ Annex 2 ICAO Rules of the Air. Appendix 2 Interception of Civil Aircraft
}

wilayah terlarang, terbatas atau daerah bahaya atau untuk menginstruksikan pesawat agar mendarat di bandar udara yang ditunjuk;

d. Bimbingan navigasi dan informasi penerbangan akan diberikan kepada pesawat udara yang diintersep melalui radio kontak oleh pesawat militer; dan

e. Dalam kasus di mana sebuah pesawat sipil yang diintersep diperlukan mendarat di wilayah overflown, bandar udara yang ditunjuk untuk pendaratan harus menunjukan pendaratan yang aman bagi pesawat yang bersangkutan.

Standar operasi prosuder intersep pesawat yang dilakukan oleh TNI AU tentunya harus mengutamakan keselamatan warga sipil, mengingat bahwa Indonesia telah meratifikasi Konvensi Genewa 1949 yang terdiri dari 4 Konvensi salah satunya dalam Konvensi mengenai perlindungan orang-orang Sipil di waktu perang. Larangan untuk menyerang orang sipil dan penduduk sipil terdapat dalam Pasal 51. Dalam pasal tersebut ditentukan bahwa orang sipil dan penduduk sipil menikmati perlindungan umum terhadap bahaya yang timbul dari operasi militer. Berdasarkan prinsip tersebut ditentukan peraturan sebagai berikut :

1) Orang sipil dan penduduk sipil tidak 
boleh dijadikan objek serangan;

2) Orang sipil menikmati perlindungan yang terdapat dalam seksi ini, kecuali dan pada waktu ia turut serta secara aktif dalam permusuhan.

Dalam hukum nasional Indonesia, pelaksanaan intersepsi terhadap pesawat sipil asing yang melanggar wilayah udara Indonesia dilakukan oleh aparat penegak hukum yaitu TNI Angkatan Udara. Berdasarkan ketentuan tersebut, TNI Angkatan Udara diberi wewenang dan tanggung jawab dalam penegakan kedaulatan dan hukum terhadap pelnggaran di wilayah udara, termasuk kawasan udara terlarang, terbatas dan daerah berbahaya sesuai dengan tugas pokoknya. Untuk mengimplementasikan pelaksanaan tugas penegakan hukum di ruang udara nasional tersebut, maka dibutuhkan peran Komando Pertahanan Udara Nasional (Kohanudnas). Kohanudnas memiliki kemampuan deteksi, identifikasi dan penindakan terhadap pesawat udara yang melakukan pelanggaran terhadap wilayah udara Republik Indonesia. Sementara itu, dalam melaksanakan tugas tersebut Kohanudnas melaksanakan Operasi Pertahanan Udara (Operasi Hanud).

Pelanggaran pesawat asing di wilayah larangan terbang Indonesia, Operasi Hanud yang dilakukan ialah Operasi Hanud Aktif. Pesawat udara yang akan dan telah memasuki kawasan udara terlarang, terbatas, dan berbahaya akan diperingatkan dan diperintahkan untuk meninggalkan wilayah tersebut oleh radar TNI Angkatan Udara. Dalam hal peringatan dan perintah tersebut tidak ditaati, dilakukan tindakan pemaksaan oleh pesawat militer untuk keluar dari wilayah yang menjadi kawasan udara terlarang, terbatas, dan berbahaya atau untuk mendarat di pangkalan udara atau bandar udara tertentu di dalam wilayah Negara Kesatuan Republik Indonesia. ${ }^{9}$

Penegakan hukum terhadap pelanggaran zona larang terbang di udara tidaklah berbeda dengan penegakan hukum terhadap pelanggaran izin terbang. Tahap awal yang dilakukan oleh TNI AU dalam upaya penegakan hukum di ruang udara adalah dengan cara $:^{10}$

1. Pangkohanudnas selaku pemegang Komando Operasi Pertahanan Udara yang mengendalikan operasi pertahanan udara memerintahkan MCC (Military Civil Coordination Center) landasan udara setempat agar mengarahkan pesawat asing tersebut untuk segera mendarat di landasan udara terdekat.

2. Jika setelah beberapa waktu kemudian tetap tidak bisa dilakukan radio contact dengan pesawat asing tersebut

\footnotetext{
${ }^{9}$ Pasal 8 Undang-Undang Penerbangan

${ }^{10}$ Dispenau. Sukhoi TNI AU Paksa Mendarat Pesawat Asing di Balikpapan. Diakses pada tanggal 8 Mei 2015 pukul 11:22 http://tniau.mil.id/berita/sukhoitniaupaksamendaratpes awatasingdibalikpapan
} 
dan tidak menunjukkan iktikad akan mendarat di landasan udara yang diperintahkan TNI AU, selanjutnya atas perintah Pangkohanudnas, maka Pangkosekhanudnas memerintahkan pesawat militer TNI AU untuk segera melakukan proses penindakan terhadap pesawat pelanggar wilayah udara Nasional.

3. Selanjutnya pesawat militer TNI AU akan melakukan "Shadowing" yang merupakan upaya untuk indentifikasi. Dalam fase ini ada kemungkinan untuk menggiring pesawat udara musuh (hostile aircraft) untuk keluar dari wilayah RI. Melalui radio pilot pesawat militer menanyakan asal dan tujuan pesawat serta status perijinan melintasi wilayah Indonesia. Jika pesawat asing tersebut tidak mempunyai ijin melintas di wilayah udara Indonesia.

Maka

Pangkosekhanudnas II memerintahkan agar pilot pesawat militer memaksa pesawat asing tersebut untuk mendarat di Landasan Udara yang telah diperintahkan.

4. Setelah mendarat di Base Operasi Landasan Udara setempat, anggota Lanud sesuai dengan prosedur forced down, segera mengamankan pilot asing tersebut guna pemeriksaaan kelengkapan surat-surat resmi seperti Flight Approval dan Flight Security

\section{Clearance.}

Jika dalam pemeriksaan penyelidikan yang dilakukan oleh TNI AU ditemukan adanya tindak pidana maka kewenangan melakukan penyidikan ini dilimpahkan kepada Penyidik Pegawai Negeri Sipil. Penyidikan yang dilakukan oleh Penyidik PNS di lingkungan TNI AU dilaksanakan sesuai dengan Perintah dari Pangkohanudnas, sedangkan penyidik PNS di luar lingkungan TNI AU diperlukan koordinasi secara lansung dengan TNI AU. Penyidik melakukan penyidikan terkait tindak pidana pelanggaran wilayah udara Indonesia, sesuai dengan kewenangan yang diberikan secara khusus oleh Undang-undang Republik Indonesia nomor 1 tahun 2009 tentang penerbangan. Kemudian setelah melakukan penyidikan, Penyidik Pegawai Negeri Sipil menyampaikan hasil penyidikan kepada Penuntut Umum melalui Pejabat Penyidik Kepolisian Negara Republik Indonesia.

Dalam Undang-undang Republik Indonesia nomor 1 tahun 2009 tentang Penerbangan telah diatur mengenai sanksisanksi yang di berikan bagi pelanggar kedaulatan di ruang udara Indonesia terutama di zona larangan terbang. Pasal 401 menyatakan bahwa;

Setiap orang yang mengoperasikan pesawat udara Indonesia atau pesawat udara asing yang memasuki kawasan udara terlarang sebagaimana dimaksud dalam Pasal 7 ayat (2) dipidana dengan 
pidana penjara paling lama 8 (delapan) tahun dan denda paling banyak Rp500.000.000,00 (lima ratus juta rupiah).

Dari pengaturan tersebut, terlihat bahwa status kawasan udara terlarang sangatlah penting karena menunjukan kedaulatan suatu negara di wilayah udaranya. Sanksi pidana yang dijatuhkan terhadap pelanggar tidak dibedakan terhadap pesawat udara Indonesia dan pesawat udara asing, terlebih lagi apakah pesawat tersebut memasuki kawasan udara terlarang dengan alasan permusuhan ataupun dengan alasan tersesat.

Selanjutnya dalam penerapan di kawasan terbatas, Undang-Undang Penerbangan memberikan sanksi sebagai berikut :

Setiap orang yang mengoperasikan pesawat udara Indonesia atau pesawat udara asing yang memasuki kawasan udara terbatas sebagaimana dimaksud dalam Pasal 7 ayat (4) dipidana dengan pidana penjara paling lama 3 (tiga) tahun atau denda paling banyak Rp500.000.000,00 (lima ratus juta rupiah).

Dalam upaya penegakan hukum di wilayah udara, Indonesia telah menerapkan zona larangan terbang serta pencegahannya sesuai dengan hukum internasional. Hukum internasional yang mengatur mengenai Penerbangan Sipil Internasional memberikan kewenangan penuh terhadap negara dalam menerapkan zona larangan terbang, namun negara tidak boleh menggunakan kekerasan dalam penegakan hukumnya terhadap pesawat sipil, seperti yang telah dibahas di dalam bab ini. Praktik pengaturan maupun penegakan hukum terhadap pelanggaran di wilayah udara Indonesia tidak terdapat unsur kekerasan. Indonesia telah menerapkan hukumnya sesuai dengan hukum internasional demi terciptanya keamanan dan keselamatan penerbangan.

\section{Penutup}

Peraturan yang mengatur mengenai kedaulatan negara di zona larangan terbang ialah dalam lingkup internasional diatur di dalam Konvensi Paris 1919 yang diatur di dalam Pasal 3 dan Pasal 4, Konvensi Chicago 1944 dalam Pasal 9, Konvensi PBB tentang Hukum Laut 1982 dalam Pasal 39 dan Pasal 53 ayat (1) dan (5). Dalam lingkup hukum nasional Indonesia diatur di dalam Undang-Undang nomor 1 tahun 2009 tentang Penerbangan dalam Pasal 7, Peraturan Pemerintah Nomor 3 tahun 2001 tentang Keamanan dan Keselamatan Penerbangan dalam Pasal 1 angka 10. Kawasan udara Indonesia dibagi dalam 3 katergori yaitu, kawasan terbatas, kawasan terlarang, dan kawasan berbahaya. Kawasan terlarang dan kawasan berbahaya merupakan zona larangan terbang, dalam kawasan terlarang pesawat udara dilarang terbang karena dibawahnya terdapat kegiatan militer dan demi menjaga keamanan negara di bidang 
militer dan penetapan ini bersifat permanen.

Sedangkan kawasan berbahaya, pesawat udara di larang terbang karena terdapat keadaan yang berbahaya di bawahnya seperti adanya aktifitas Search and Rescue dalam wilayah bencana. Penegakan hukum terhadap zona larangan terbang adalah wewenang dari TNI AU, dalam melakukan penegakan hukum tersebut pesawat yang melakukan pelanggaran di zona larangan terbang Indonesia akan segera terdeteksi oleh radar TNI AU kemudian akan melakukan kontak dengan pesawat tersebut untuk meninggalkan wilayah larangan terbang dan/atau mengarahkan pesawat untuk mendarat di landasan udara terdekat. Jika pesawat tersebut menolak menolak maka Pesawat militer milik TNI AU akan melakukan pengejaran seketika terhadap pesawat tersebut dan selanjutnya melakukan intercept (pencegatan) kemudian pesawat diarahkan untuk mendarat di landasan udara terdekat untuk dilakukan interogasi dan pengenaan denda bagi pesawat yang melanggar.

\section{Daftar Pustaka \\ Buku}

Muhamad,A. (2004). Hukum dan Penelitian Hukum, Bandung : PT. Citra Bhakti.

Busroh,A.D. (2011). Ilmu Negara, Jakarta: Bumi Aksara.

Sahmin,A. (2012). Hukum Udara dan Ruang Angkasa, Palembang : Unsri Pers.
Aust, A. (2002). Handbook Of International, London : Cambridge Unversity Press.

Nijeholt, L,F,J. (1910). Air Sovereignty. New York : Springer, New York.

Glahn,G.V. (2006). The Law Among Nations, Inggris : Oxford University Press.

Parthiana, I.W. (2003). Pengantar Hukum Internasional. Bandung : Mandar Maju.

Starke, J.G. (2008). Pengantar Hukum Internasional, Yogyakarta : Sinar Grafika.

Martono, K. (1995). Hukum Udara, Angkutan Udara dan Hukum Angkasa, Hukum Laut Internasional (Buku Kedua). Bandung : Mandar Maju.

dan Ahmad Sudiro. (2011). Hukum Angkutan Udara Berdasarkan UU RI No. 1 Tahun 2009. Jakarta : Rajawali Pers.

dan Ahmad Sudiro. (2012). Hukum Udara Nasional dan Internasional Publik, Jakarta : Rajawali Pers.

Kurnia, M.P. (2011). Hukum Kewilayahan Indonesia Harmonisasi Pengembangan Kawasan Perbatasan Berbasis Teknologi Geospasia, Malang : UB Pers.

Milde, M. (2008). Essential Air and Space Law (International Law and ICAO). Netherland : Eleven International Publishing.

Kusumaatmadja, M. dan Etty R. Agoes. (2003). Pengantar Hukum Internasional, Bandung: Alumni.

Huda, N. (2010). Ilmu Negara, Jakarta : Rajawali Pers.

Abdurasyid, P. (1972). Kedaulatan Negara 
di Ruang Udara, Jakarta : Pusat Penelitian Hukum Udara.

Sefriani. (2010). Hukum Internasional Suatu Pengantar. Jakarta : Rajawali Pers.

Soekanto, S. \& Mamudji, S.(2003). Penelitian Hukum Normatif : Suatu Tinjauan Singkat. Jakarta : Rajawali Pers.

Hadiwijoyo, S.S. (2011) Perbatasan Negara dalam Dimensi Hukum Internasional. Yogyakarta : Graha Ilmu.

Ali, Z. (2011). Metode Penelitian Hukum, Jakarta : Penerbit Sinar Grafika.

\section{Jurnal Dan Skripsi}

Alexander Benard, Lessons from Iraq and Bosnia on the Theory and Practice of No-fly Zones, The Journal of Strategic Studies, 2004

Asaf Degani, The Crash of Korean Air Lines Flight 007, NASA Ames Research Center, Mountain View, California, 2001

Dita Anggraini Wibowo, Pelanggaran Kedaulatan Di Wilayah Udara Negara Indonesia Oleh Pesawat Sipil Asing, Fakultas Hukum Universitas Brawijaya, 2014

Enna Nurhaina Burhan, Konsep Zona Larangan Terbang dan Hukum Udara Internasional, Waspada, 26 Februari 1999

Hendini Widia Utami, Pemberlakuan Zona Larangan Terbang Di Suriah Menurut Ketentuan Hukum Internasional, Skripsi, Universitas Sumatera Utara, 2014

Yan Jefri Barus, Yurisdiksi Wilayah Udara Suatu Negara Dalam Perspektif Hukum Internasional, Fakultas Hukum Universitas Sumatera Utara,
2014

\section{Konvensi/Treaty/Agreement}

Konvensi Paris 1919 tentang Convention Relating To The Regulation Of Aerial Navigation

Konvensi Montevideo 1933 tentang Hak dan Kewajiban Negara

Konvensi Chicago 1944 tentang The Convention On International Civil Aviation International Air Transport Agreement 1944

Konvensi Jenewa ke-4 1949 mengenai Perlindungan Orang Sipil di Masa Perang

Konvensi Perserikatan Bangsa-Bangsa tentang Hukum Laut 1982 (United Nation Convention of Law Of The Sea 1982)

International Air Transport Agreement 1944

International Civil Air Organisation Annex 2 tentang Rule of the Air

\section{Peraturan Perundang-undangan}

Undang-Undang Dasar Negara Kesatuan Republik Indonesia Tahun 1945

Undang-Undang Republik Indonesia Nomor 1 Tahun 2009 tentang Penerbangan

Undang-Undang Republik Indonesia Nomor 3 Tahun 2002 tentang Pertahanan Negara

Peraturan Pemerintah Republik Indonesia Nomor 3 Tahun 2001 tentang Keamanan dan Keselamatan Penerbangan 